\title{
BEHAVIORAL ECONOMICS: DEVELOPMENT, CONDITION AND PERSPECTIVES
}

\author{
Dimitar Kanev ${ }^{1}$ and Venelin Terziev ${ }^{2}$ \\ ${ }^{1}$ Professor, D.Sc. (Ec.), Ph.D. Nikola Vaptsarov Naval Academy, Varna, Bulgaria \\ ${ }^{2}$ Professor, D.Sc. (Ec.), D.Sc. (National security), Ph.D., Angel Kanchev University of Rousse, \\ Rousse, Bulgaria; National Military University, Veliko Tarnovo, Bulgaria \\ University of Telecommunications and Post, Sofia, Bulgaria, terziev@skmat.com
}

\begin{abstract}
The study examines the place of behavioral economics in the structure of economic science and the practice of state regulating. The thesis that neoclassicism is an appropriate normative approach for analyzing human behavior is defended but the comparative advantages are on the side of behavioral economics in the answers of inscriptive, diagnostic, prognostic and perspective questions. It tracks the historical roots, the ideas of behavioral economics for the limited rationality, will and egoism are presented in short as well as the contribution of behavioral approach to the state intervention's ideology and practice. The libertarian paternalism idea and its role for the transformation of "state of wealth" into the gaining clearer and clearer outlines "new paternalistic state" are presented.
\end{abstract}

Keywords: behavioral economics, libertarian paternalism, nudge

\section{INTRODUCTION}

There is consensus existing in the behavioral sciences that three types of questions need theoretical explanation. The first is the normative question „How should people act“. The second types of questions are directed towards three problems: the descriptive „How do people actually act", the diagnostic "Why they act this way" and the prognosis "What results their behavior would lead to". The third type of questions is the perspective question „How to achieve that the people act the way they should act". Although desirable, a theoretical construction is not able to give answer to all three types of questions. (Thaler, 2016)

Undoubtedly, the neoclassical idea for "Homo Economicus” is successful in finding normative answers for the ideal we should strive for. "Homo Economicus" is rational, possesses unlimited possibilities to acquire and process necessary information, reacts in a predictable way to the stimuli created by the market and public institutions, pursues his own interest and has the will to realize his goals. The assumption for rationality is altogether simplified, powerful and precise enough tool, with which one can quest for descriptive 
answers and prognosticate wide range of economical phenomena. However, there are phenomena and facts that are in contradiction with the fundamental assumptions for rationality.

We difficultly estimate the possible outcomes and the probability of their occurrence. We overestimate ourselves and act with prejudice towards the others. Our optimism is unduly high and at the same time, we exaggerate the damage of possible losses. We use mental models that frame information the way we often interpret it incompletely and wrongly. Our choices depend on the context and we show tendency for anchoring to useless and unspecified information. We stick to the status quo, follow our previous behavior or the others, show conservatism and avoid changes, even when they are urgent. We are led by reciprocity and often turn our back to our own interests: we are ready to allocate resources and efforts to encourage those, who behaved fairly, and to penalize injustice.

In general, most of the people do not succeed in maximizing the expected usefulness and apply simplified but wrong strategies for decision-making and make better choices when having limited number of alternatives. They often act against their own interest: they postpone important things such as prophylactic examinations, qualification and saving for retirement, they stick to the option implicitly even if it is not the best choice of theirs, invest unreasonably, tend to accept tricky advices and to vote for unreasonable political projects, etc.

All these are examples of behavioral failures, which cannot be integrated in the picture of neoclassical economics. They are manifested particularly strongly at: time discrepancy between decisions' benefits and losses (savings and insurances, consumption of alcohol or other problems of self-control); need of expert knowledge (choosing a leasing plan or another financial product); low repetition of decisions and impossibility to learn from experience (family binding, purchase of home and car, how many children to have and the choice of a career); bad feedback (healthcare, education and savings); choosing among unknown alternatives (working place, medical procedure, school or vacation package); experience accumulation is damaging (the negative dependences). (Thaler \& Sunstain, 2014). The list practically means that there are behavioral failures in almost all situations and activities, except the repeating simple deals. Besides, they are universal. Despite his intelligence, education, experience, wealth or influence, at certain circumstances and regarding certain issues, each one of us is limited within his rationality, self-control and egoism. (Mullainathan \& Thaler, 2001)

Not considering the limitation of rationality, self-control and egoism and the resulting behavioral failures prevents neoclassical economics from presenting correct descriptive picture of human behavior and forces for its idealized understanding for "Homo Economicus" to be corrected. A new stream in the theory of economics that became popular as behavioral economics ${ }^{1}$ tries to put the real human and the behavioral failures in the center of the economic analysis attention in the last forty years. Its goal is to improve the reality and quality of economic analysis, which would result in better prognosis of the real humans' behavior and in formulating better recommendations for the followed policy. (Camerer, et al., 2004)

The present article aims to summarize the achievements and challenges ahead of behavioral economics in achieving its purposes. It would track the sources and the logic of its development, would present its main achievements worldwide and at home and would outline its role and perspectives within the frame of modern economic sciences and the state governing practice.

\section{SOURCES AND DEVELOPMENT}

The roots of the behavioral economics' methodological approach are in the remote 1759. Then the 35-year old teacher in Ethics in the University of Glasgow Adam Smith publishes his first big work, Theory of Moral Sentiments. There he uncovers some features of human behavior that cannot be integrated in the idea for the "economic person”. (Ashraf, et al., 2005). Among them are the over-confidence („the haughty selfreliance on the own capabilities that most of the people possess") and the lack of foresight at choices that regard the future (,the pleasure we will get in ten years is interested for us much less compared to what we

\footnotetext{
${ }^{1}$ Some authors (Angner \& Loewenstein, 2012) consider that the more correct name is "cognitive”, not "behavioural” economics. Our opinion coincides with this position. The term „behavioural” is not correct because of two reasons. First, it is not informative as far as all economic streams' subject is human behavior and in this sense, they are all „behavioural“. Second, it is tricky. behavioural economics' methodological fundament is the cognitive psychology, not the behaviourism. Behaviourism in psychology is not only a counter point of cognitive psychology, but it is also the stream, on which the foundations of neoclassicism are constructed - the economic paradigm, which is the main object of critics by the behavioural economics. When introduced in 1958, its authors Harold Johnson and Kenneth Boulding perhaps did not consider these two arguments, may be because of the cognitive psychology condition at the time, too. Then traditionally the mistake is repeated and as much as it is repeated, the less noticeable it becomes. This demonstrates how the behavioural economics itself is victim of the deformations it is called to uncover and neutralize.
} 
can enjoy today"). Adam Smith also reasons for the first time about avoiding losses, pointing that we suffer more when we fall from good to worse state than we enjoy it when the state changes from bad to better. $\mathrm{He}$ admits that we possess the natural trend to take care of ourselves because prudence dictates so. However, as far as we are also social beings, we are gifted with natural sympathy with the others, with striving towards justice and virtues like involvement, self-control, self-criticism and conscience. In the process of taking many of our decisions, we do not need to think, but we are led by ethic rules and norms. Despite our passing emotions and interests, the raised by them "sentiment of duty", proud and shame help us observe the principles of moral and unpremeditatedly to contribute to the others' happiness and to the public peace. For Adam Smith legal penalties and encouragements may be aim the same results but they could never be so consistent, immediate and effective as conscience and moral rules dictated by nature and society.

Psychology and sociology do not exist as independent behavioral sciences in the first years of economic theory development and economists pay considerable attention to moral, sentiments, human impulses and emotions. Their theoretical tools like the Law of Diminishing Marginal Utility for example, use psychological arguments. Despite the proclaimed respect to Adam Smith, since the $70^{\mathrm{s}}$ of the $20^{\text {th }}$ century, influenced by the works of William Jevons, Karl Menger, Leon Walras and Francis Edgeworth, economic theory takes away from his intellectual heritage. Then the emerging neoclassical paradigm starts referring more and more critically towards the hedonistic assumptions of Jeremy Bentham's Utility Theory, economy gains the image of a natural science that explains human behavior as rational and relies fundamentally solely on the behaviorist stream of psychology. The human act itself becomes its problem, not the motives behind it; the results, not the processes that caused them; what people do, not why they do it; what the problems in the relations between the separate agents are, not the problems in each one of them. (Camerer, et al., 2004)

The neoclassical models of rational choice dominate in economics until the end of the $20^{\text {th }}$ century. Economics and the other social sciences use them to explain in logic and convincing way not only the behavior of the market and how the companies stimulate their employees and the consumers react to the changes in prices. Neoclassical economics' application field considerably broadens in the course of years and includes such issues as voting at elections, family behavior, education and healthcare, dependencies, criminality, terrorism and armament.

Neoclassical stream attracts numerous researchers but the searches of some of them lead to results that contradict the neoclassical theories that had inspired them. Strong is the critics coming from other sides, too. In his General Theory of Employment, Interest and Money John M. Keynes uses many times as arguments „animal instincts”, "spontaneous optimism”, „money illusion”, „tendency for stubbornness in making mistakes” and other social-psychological characteristics that cannot be attached to the understanding for the optimizing "Homo Economicus". Fr. Von Hayek also emphasizes that Rational behavior is not a precondition in economic theory although it is often presented to be. The theory's main statement is rather that competition would make people act rationally in order to make their own living." (Hayek, 1998, p. 98). Enough evidence appears in the second half of the $20^{\text {th }}$ century that the principles of rationality are unrealistic and that the economic theory evolution anticipates considerably human evolution. This gradually restores the connection of economics with the rest of the behavioral sciences, directing researchers' attention towards actual behavior and psychology new achievements in fields like thinking, problems solving and decision making.

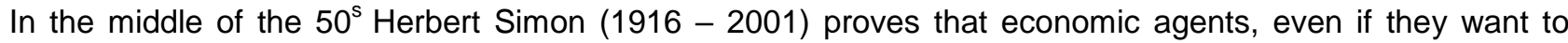
maximize their wealth, they do not have the necessary information, cognitive capacity and time to process the available information and instead of following the postulates of rationality, they find "satisfying" solutions. As far as they are not able to catch and make sense of all the available information, they react consciously to only a small part of it and act in a way different from the way they would follow at the availability of all the information.

In the beginning of the sixties Vernon Smith (1927 - ), also awarded Noble Memorial Prize in Economic Sciences in 2002, brings into question some of the basic assumptions of the rational choice model, which concern markets functioning. V. Smith conducts experiments to simulate markets functioning. This sets the beginning of the so called "experimental economics“ and results in a remarkable discovery: although the participants in the experiments do not have full information and are not always rational in their behavior, market equilibrium is anyway achieved. This means that in methodological aspect we do not need rational individuals to explain the rational market result.

In 1967, the German-born American psychologist Ulric Neisser (1928 - 2002) published his work of Cognitive Psychology, with which he gave the name to this new branch of psychology. He develops it as inter-disciplinary stream that unites intuitive models of classical philosophical thinking with the experimental psychology's empiric approach. 
A year later, in 1968, Howard Raiffa published his book „Decision Analysis: Introductory Lectures on Choice under Uncertainty" and sets the beginning of modern decision making theory. The same year he, John Hammond and Ralph Keeney publish an article that describes seven psychological traps, which could negatively influence the way of decision making, namely the traps of: (1) anchoring - giving disproportionate weight to unessential incidental information; (2) status quo - sticking to the present choices even if better alternatives exist; (3) the sunk cost - binding and consecutive repetition of mistakes from the past; (4) confirming evidence - looking for status quo confirming information and discounting opposing information; (5) overconfidence - overestimating the accuracy of own forecast; (6) the prudence - over-caution at estimating uncertain events; and (7) the recallability trap - giving undue weight to recent, dramatic events.

The ideas of Herbert Simon, Vernon Smith, Ulric Neisser and Howard Raiffa are the base for a huge jump for the economic agents' behavior understanding. It was carried out by the Israeli cognitive psychologists Daniel Kahneman $(1934-)$ and Amos Tversky $(1937-1996)$ in the last quarter of the $20^{\text {th }}$ century. They discover number of features of human thinking that offer natural explanation of observed reactions and anomalies in the made decisions.

The first important conclusion out of Kahneman and Tversky's studies is that thinking is dual and is predominantly automatic, not rational. (Tversky \& Kahneman, 1974). Automatic thinking resorts to what comes to our mind without efforts. In great part of the time, instead of making complicated calculations and thinking over all possible ways of acting we prefer simple decisions and use "short mental paths" or "heuristics". Our ability of elaborating intuitive assessments plays the main role in this way of thinking and acting. It has formed long before logic thinking developed and is common for humans and animals. Intuition is characterized by speed and automatism necessary for surviving. It is based on the accumulated knowledge and experience from the past but often has no answer to the more difficult issues we face in our social interactions, in professional field or in economic relations. Then intuitive system consults rational thinking. It is slower, is managed by formal rules, has a lot of knowledge and this makes it flexible, but at the same time is way lazier and tend to save its efforts.

The last fact is easily explained. Brain is very powerful tool for assessment and decision-making. However, it is much ineffective. Typical human brain is just two percent of the total body weight but consumes $20 \%$ of the body energy. More, its energy ineffectiveness does not even allow its full capacity to be used. Brain cannot set in simultaneous operation more than two percent of its neurons. If it exceeds that limit, the reserves of the used fuel - glucoses - exhausts so rapidly that the person loses consciousness. (Medina, 2011). Because of these restraints, each economy of intellectual efforts and time is much desirable. That is why, when possible, consciousness always acts intuitively and processes automatically sensuous signals as well as the information about gains and losses, wealth, prestige and social hierarchies. Intuitive system quickly and imperceptibly pre-formulates the received information into its abstract representation and leads to the relevant act.

The second revolutionary contribution of Kahneman and Tversky comes in 1979 with their article Prospect Theory: Decisions under Risk. (Kahneman \& Tversky, 1979). Here they present evidences for number of animalizes that contradict the Expected Utility Theory and offer an alternative theory, based on several principles: separate estimating of each possible outcome toward particular reference point, losses exceptive avoidance and asymmetric estimation of benefits and losses, different attitude towards the risk at gains and losses. Their article is published in the renowned magazine of Econometrica and is one of the most cited publications of the magazine - more than 40000 times.

When Daniel Kahneman summarized his ideas in his book Thinking in 2011 (Kahneman, 2012), the Economist magazine compared the scholar's achievements with the ones of Copernicus and Darwin: „As Copernicus removed the Earth from the center of the universe and Darwin knocked humans off their biological perch, Mr Kahneman has shown that we are not the paragons of reason we assume ourselves to be“. (The Economist, 2011). Actually, Kahneman's position is a way more moderate. According to him, „The main feature of agents is not that they reason wrongly, but that they often act intuitively. And that their behavior is not guided by what they are capable to calculate, but what they happen to see at the certain moment". (Kahneman, 2003). Said in other words, the problem behind the often lack of rationality is not that people are fool of undereducated but that they are driven by intuition and emotions, i.e. that they are humans.

The collaboration of Kahneman and Tversky's in the 80 s of the $20^{\text {th }}$ century with the then young American economist Richard Thaler (1945 - ) results in the occurrence of behavioral economics as a separate stream of economic theory. 
Behavioral anomalies that cannot be explained by the traditional economic models become motive for progress and main object of research in the first steps of behavioral economics. It is revealed they are natural and systematic and this allows them being studied and being predictable. To analyze them, behavioral economics integrates the newest theories and hypothesis of economics and the latest achievements of cognitive psychology, social psychology, psychophysiology, evolutionary economics, sociology and even neurology. Within this integration, behavioral economics takes from traditional economics the interest towards decision's results, from the cognitive psychology and neurology - the interest towards the very process of decision making, and from sociology - the interest towards environment and norms impact. It is already interested in not only what choice people make but also why they do it and what processes define their ratiocinations, estimations, decisions and actions. Thus understanding about human behavior is achieved, where the assumption for rationality is corrected.

Behavioral economics ideas do not exhaust with the explanation of human behavior and behavioral deviations from rationality. Predictability of behavioral failures allows them not only being recognized and reported but also being overcome. (Ariely, 2012). Two articles published in 2003 - Libertarian Paternalism (Thaler \& Sunstein, 2003) and Regulation for conservatives: Behavioral Economics and the Case for the Asymmetric Paternalism (Camerer, et al., 2003), point the intellectual connection between the condition, in which people make behavioral mistakes and the questions whether, when and how these mistakes to be corrected. The conclusions turn behavioral economics into political doctrine that gives the grounds of new responsibilities and new scope of tools for the state to intervene, which change the context of individual choices the way that they: (1) increase individual wealth and help people achieve their own normative preferences and (2) do not limit the individual rights and freedom of choice. In 2008 this doctrine gets its own popular name - „nudge") (Thaler \& Sunstein, 2014), although the authors of the book bearing the same name prefer it to be called "Liebratrian Paternalism".

\section{NUDGING AS CONTRIBUTION IN THE IDEOLOGY AND TOOLS OF STATE REGULATING}

"Each form of intervention in individual choices, if it contributes to the effective removal of the problems with behavioral failures" is desired and acceptable for behavioral economists. (Rizzo \& Whitman, 2009). Thus, in contract to neoclassical paradigm, an extensive state intervention is allowed including the cases, when the decisions regard only the ones, who take them (even at the absence of failures and distribution problems).

The scope of tools and methods of governmental intervention is extremely wide. On one hand, behavioral economy re-estimates many of the traditional plans and regulatory tools, suggesting conceptual frame for ones and has serious doubts on the effectiveness of others. On the other hand, it introduces new, nonstandard tool of „behavioral " policy in society's agenda. Their character is paternalistic and they may have impact upon: (1) the results, without disturbing people's actions or opinions (automatic transfer of additional mandatory insurance payments from private funds into the National Insurance Institute); (2) the actions, without changing the beliefs (the fines for exceeded speed limit); (3) the beliefs, aiming influence on the actions (educational campaigns on the damage of overweight); (4) the preferences, no matter if it changes beliefs (the warning signs on the cigarette boxes and commercials).

However, not all tools of paternalistic intervention are equally preferred for the behavioral approach. (Sunstein, 2013)

First, the preferred is the paternalism that affects the means, not the goals. For example, if you would like to save funds, you'd better use energy-saving and reliable appliances. Directing your choice towards such type of appliances through information on the labels on the electric power consumption or through imposing standard of power effectiveness does not disturb your goal, but helps you achieving it. Navigation systems integration in the automobiles has the same effect. You decide where you would like to go and the navigation system helps you do it with the least expenses of time and fuel. „Smart" pedestrians with inscription "Look right" or "Look left" are also an example for tools paternalism. Focusing the attention on the correct direction, they just help the pedestrians to do safely what they themselves had decided to do - to cross the street. The same is with the regulations for mandatory belts in automobiles and helmets for motor-bikers, the labels containing the ingredients of food and the standards for their production. Paternalism of tools respects the individual goals - you to save, to move safely, to make informed decisions of your own interest - but considers that people's actions are not always complied with them, and directs their actions in the correct direction.

Second, behavioral approach prefers the "soft" forms of paternalism. These forms affect without imposing high expenditures. Examples are the small and moderate fines, the warnings, the educational programmes, the requirements for information about products, including the energy effectiveness and the fuel expense, 
the regulations on the place, time, packaging and way of selling of products, the options by implication and the automatic inclusion in a saving or insurance plan.

Behavioral economists support the "hard" forms and the paternalism of goals in two cases. The first is when they bring much bigger benefits than expenses. An example is the imposing of energy effectiveness and fuel expense standards, the ban for drug use, the frightening pictures on the consequences of smoking upon the cigarette boxes that overexpose problems, etc. Paternalistic interventions are asymmetric in all similar cases: „.... they do great good to the ones, who make mistakes, and at the same time, impose little or no expenses on those, who are completely rational. Such regulations are relatively harmless for the ones, who make decisions that correspond to their best interest, whole, at the same time, are favorable for those making nonoptimal decisions". (Camerer, et al., 2003) The second one is when they are demanded by John St. Mill's harm principle. However, essentially such constraints are not purely paternalistic, because they are not grounded on protection of people's own interests, but on the principle that everyone is free to do what he wants under the condition not to disturb anybody else's rights. In these two cases, if the decisions are left to the people themselves, then they would strive for getting insignificant short-term benefits and would neglect the much bigger long-term expenses for them as well as the damages they cause to the others with their own behavior.

Third, libertarian paternalism prefers open, public and directed to rational system tools for "nudging“. They are meant for taking out of the automatic mode and for alarming the rational systems through drawing the attention and focusing upon the action, that is taking place at the moment. The "nudged ones" are aware with these aims before undertaking action and if they do not accept them, they can follow another type of behavior, too. Not opened, hidden and directed towards the automatic system „nudging” works the way that the ones towards whom it is directed, cannot uncover neither the intentions nor the means, by which behavior change is sought. No matter whether they cause unconscious or conscious reactions, their nontransparency does not allow people even to understand they are subject to correcting influence, and this means that practically, they do not have the freedom and cannot avoid it. As a result "nudging" may easily turn into manipulation of others' choices and behavior and open the door to their unconscious in order thoughts, desires, fears, worries or model of behavior to be put inside to lead them to actions that are not of interest for them. And, as far as this happens non-transparently, "nudging" would stay unnoticed and "the ones who initiate the nudging" would avoid the control on their actions and the responsibility for them.

The pointed three characteristics contain the contribution of libertarian paternalism to state regulation's ideology and the practice. It extends the boundaries of admissible state intervention in people's lives compared to neo-liberalism, but the position it proclaims is much more balanced, prudent and moderate than the one of traditional paternalists. However, critics are not few. Radical opponents of neoclassicism consider it too soft and inconsistent. Neoclassicism supporters consider it form of manipulation of civilians and of state directing them towards actions they have not agreed and cannot avoid. (Easton, 2014)

\section{CRITICS AND REACTIONS}

The main critics are fed by the possibility for paternalistic manipulations. (Bovens, 2008). Limited rationality and will do not mean people are fool. They might be aware of their own deficit of self-control when they choose chips instead salad but consciously and certainly to prefer the first if they are not on diet. Why should someone intervene in their choice and change it? If "nudging“ is premeditated attempt to influence others' behavior and decisions, which is based on certain values and has certain goals, what is the guarantee that these values and goals comply with own values and goals of the nudged ones? How to guarantee that "nudging" is "for good" and how to avoid „evil nudges"? What makes libertarian paternalism's moral different from the one of traditional paternalism if, in the long run, it also forces people without their agreement and often without them being aware, to act in certain direction? How can the "initiators of nudging " uncover "the real" preferences of others if the latter, being rationally limited, are not aware of their own preferences and do not even think about them. If people cannot achieve what they would like to, because of their deformations, what prevents the „initiators of nudging" from the same deformations they should save the others from?

Libertarian paternalism faces critics also because of the effect upon stimuli and responsibility of people. It establishes the relations between state and civilians after the model of the relations between adults and children. "Nudging" children is much easier than adults. That is why most often the „nudging" ones behave in infantile manner with the "nudged" ones. In most cases their behavior uses arguments, symbols, words and intonation as if speaking of children with impediments in their growth or mentally ill. Manipulative potential of that is dangerous and should be taken into consideration. If someone behaves with a person this way, as if he is unconscious child, then his reaction would be lack of critical estimation and the desired behavior and choices would be easier achieved. (Chomsky, 2016) 
Infantilization of civilians is a problem because of yet one more reason. It creates danger of state intervention escalation: the more infantile and deprived of stimuli to develop their good decision making potential the civilians are, the more care from the state they need; but the greater these cares are, the bigger civilians' irresponsibility and dependency grow. (Furedi, 2011). Thus, practical application of "nudge" tools may result in self-performing prophecy: decreasing ability of people to learn from their mistakes and to make good decisions would lead to more people making wrong decisions, which, on its part, justifies new interventions through „nudges“. (White, 2013)

Not the last, libertarian paternalism is also criticized for it uses peripheral mechanisms for influence and can achieve only shallow and short-term changes. (Cialdini, 2005). As far as it avoids the main way of influence, it does not provoke long-term transformation of attitudes and is not able to lead to long-term changes in behavior. (Salazar, 2012; Goodwin, 2012)

All these issues are serious and behavioral economics agrees they have their grounds. It admits they cannot be overcome solely through greater attention towards the selection, expert background, moral and motivation of the "choice architects". Two more types of measures are necessary. The first one is to use predominantly the forms of soft paternalism and transparent nudges that are directed towards the rational system, and to avoid hard paternalism and non-transparent nudges, particularly the ones using the automatic system of thinking as a channel for influence. Second, emphasis should be put on enhancing personal responsibility of people for their own present and future well-being as well as on the formation of knowledge and skills in everyone to be able himself to "nudge" his own behavior in the desired direction, to understand the techniques and methods used to be manipulated and controlled against his will, and to prevent himself from undesired and "evil nudges". The latter means to pay serious attention to study and increase critical weight of factors that raise the rationality level, for example education, specialized training on the reasons for behavioral mistakes and techniques for prevention from them, building public values and norms, construction of self-control supporting infrastructure, etc. (Prentice, 2015)

\section{NEW THEORIES AND RECOGNITION}

Despite these critics, behavioral economics gains new territories in the recent years. The main reason is that it works, where the others fail. While the economic processes surprise the adherents of traditional approaches in the first decade of the new century, behavioral economists succeed in prognosticating them. Robert Shiller with his book Irrational Exuberance (2000), Hersh Shefrin, author of Beyond Greed and Fear: Understanding behavioral Finance and the Psychology of Investing (2000), Andrei Shleifer and Meir Statman, authors of Inefficient Markets: An Introduction to behavioral Finance (2000) have significant contribution to that.

All those give some of the behavioral economists grounds for direct attack against the dominating neoclassical economic theory. „We pay awful price for our blind faith in the power of the invisible hand“, Dan Ariely considers. „Neoclassical theory is inaccurate. It does not allow us to understand why economy progresses at leaps." - Nobel laureates George Akerlof (1940 - ) and Robert Shiller (1946 - ) diagnose in their book Animal Spirits. And explain „how economy actually functions, when people are really human“, they present ambitious programme: „To achieve what existing theory have not been able to realize."

Behavioral economy adherents gain bigger and bigger recognition within the economic sphere since the beginning of the new century. In October 2004 Eugene Fama, the founder of effective markets theory, admits for Wall Street Journal: Shares prices could become irrational to a certain extent. Even Alan Greenspan, who serves as pillar of neoclassical ideas for many years and leads United States Federal Reserve between 1987 and 2006, notes that behavioral economics does not enervate completely neoclassical approach but plays crucial role in the process of investors' decision making: September of 2008 is turning moment for all analysts, including me. It forces for our macro models to include animal instincts, which dominate finances.

Symbol of the recognition of behavioral approach achievements and possibilities is the prizes of the Swedish Central Bank in memory of Alfred Nobel, awarded to Herbert Simon in 1978, to George Akerlof in 2001, to Daniel Kahneman in 2002, to Thomas Schelling in 2005 and to Robert Shiller in 2013, as well as the John Bates Clark medal for Andrei Shleifer in 1999 and for Matthew Rabin in 2003 and the bronze medal of the French National Center for Scientific Research (CNRS) for Davis Masclet in 2012.

Cognitive deviations referred to as "curio" by traditional economists, are studied already in details in respected academic editions. The number of their publications and quoting increase exponentially. The three specialized editions in the field of behavioral economics - Journal of Economic Behavior \& Organization, Journal of Economic Psychology and Journal of behavioral and Experimental Economics (former Journal of Socio-Economics) - are prestigious and have a high rating. 
Today behavioral economics is taught and developed in the most prestigious American universities Harvard University, the Massachusetts Institute of Technology, Stanford University, Berkeley, University of California, the University of Chicago, Columbia University and Princeton University. Leading in this field in France is the Group for Economic Analysis and Theory (GATE) in Lyon and in the Toulouse School of Economics. In Canada - this is the University of Toronto. In Great Britain - it is the London School of Economics and the University of Warwick. The Institute for New Economic Thinking - a brain trust, founded in 2009 thanks to the fifty million dollars donated by George Soros - also puts behavioral economics in the centre of its researches.

The application field of the stream is also extending. Similarly to the neoclassical approach „economic imperialism", it gradually embraces the traditional territories of many other social sciences. behavioral Law and Economics (Jolls, Sunstein \& Thaler, 1998; Sunstein, 2000), Behavioral Finances (Shleifer, 2000), Behavioral Economics of Development (Mullainathan, 2010), Behavioral Public Finances (McCaffery \& Slemrod, 2006), Behavioral Theory of Games (Camerer C. , 2003) and behavioral Macroeconomics (Akerlof, 2003) develop as separate branches. All of them are on their way up and not only extend the influence of behavioral economics, but also enrich its core, supplying it with new ideas, examples and arguments.

Behavioral economics enjoys up going success yet among the wide audience. Readers buy as hot cake books like Blink by Malcolm Gladwell, Nudge by Richard Thaler and Cass Sunstain, Influence: The Psychology of Persuasion and Pre-Suasion of Robert Cialdini and Dan Ariely's Predictably Irrational, being thirsty to understand why they take „wrong" decisions so often and how to avoid them.

Even film industry turns directly to behavioral economics. The film that got five Oscar nominations in 2016, The Big Short, presents not only the understanding of behavioral economics about the world financial crash of 2008 and how human ignorance, stupidity, thoughtlessness, negligence and carelessness, combined with greed and arrogance, can collapse economy and civilization for a day. The film uses also behavioral economics' advices how pretty complicated financial terms and operations should be communicated - the explanation should be simpler and should be made by liked people, who dominate media space.

Within the last decade behavioral economists increase considerably their political influence, too, and applications of their suggestions can be found in fields like healthcare, savings, finances, traffic safety, employment, discrimination, environmental protection and consumer protection. (Sunstein \& Reisch, 2017)

Lasting interest towards the behavioral economics' ideas exists in Great Britain, too. The first in the world specialized team - behavioral Insight Team, BIT, functions to the prime minister's office since 2010. BIT work gives practical results and its ideas for improving safety, education, social protection, healthcare, tax and fines collectability, energy efficiency, alcohol and cigarettes consumption reduction among young people, consumer protection and organs donation registering are already in operation. Only for the period 2011-2012 BIT work has brought benefits that exceed the expenses for its functioning 22 times. According to current data, the savings from the group's introduced recommendations within the next five years would make up more than one billion pounds. In 2014 the group consisting of 14 members working in London is partially privatized. Its members are about 100 people now. They are based in London, Manchester, New York, Singapore and Sidney and fulfill tasks of the governments of USA, Great Britain, Australia, Canada, the Netherlands, Mexico, Moldova, Poland and other countries.

As president of the United States, Barack Obama also refers to behavioral ideas many times in his speeches. In addition, he states that he "grounds his policies not upon abstract models... but upon real fact about how people act", i.e. cleared from the delicacy of the expression that is led not by the neoclassical but by the behavioral economics. The Time Magazine calls the group of his 29 close advisers, among whom Richard Thaler, Dan Ariely, Cass Sunstein and Daniel Kahneman, „behavioral dream team”, which goal - „to transform the state", is pursued with the behavioral economics recommendations. (Grunwald, 2009). Since 2014 a subcommittee to the National Science and Technology Committee functions in the White House Social and behavioral Sciences Team, https://sbst.gov/. The group works actively and publishes annual reports and many of the behavioral economists' suggestions are already realized in practice - the ideas for health insuring and retiring plans $401(\mathrm{~K})$ reforms, attracting of servicemen to the TSP saving plans, greenhouse gases reduction, organs donating organization, tax return system, the obligatory information about energy efficiency, fuel expense and the products contents. (Social and behavioral Sciences Team, 2016)

Great Britain and the USA are not the only ones interested in the behavioral approach. „Nudge" mechanisms are applied in more than 150 countries (OECD, 2017), and in many there are functioning formal structures that elaborate, suggest and introduce initiatives based on behavioral economics. An Innovation Hub to the Privy Council Office consultative committee is established in 2015 in Canada. The Hub collaborates with Canadian universities and scientists interested in behavioral approach for conduction of its experiments. In 
2016, the Australian government establishes Behavioral Economics Team, which functions as part of the prime minister's office. Centralized consultative structures exist also in Chile (Laboratorio de Gobierno), in France (Secretariat-General for Government Modernization), in Germany (Staff of Policy Planning Unit, the Federal Chancellery), etc. The approach in the Netherlands is different, 11 ministries and regulative bodies are included in the network behavioral Insights Network, initiated in 2014. The Ministry of Economics is assigned the role of network's secretariat, which connects the groups and experts from various ministries and ensures the collaboration and knowledge sharing. European Commission uses the behavioral approach yet in 2008. At first, behavioral ideas develop within the Commission's research center, Joint Research Centre (JRC). Specialized part is set in JRC since 2014 - Foresight and behavioral Insight Unit (FBIU), and since 2015, one more section functions to the EC - the EU Policy Lab. In 2016 FBIU analyses the progress of the behavioral approach application in the member states and publishes its conclusions. (European Commission, 2016). The reports Green Behavior (2012) and Nudging the Lifestyle for Better Health (Piniewski, et al., 2011) are among the EC publications, again full of behavioral recommendations. The analysis and recommendations in these and in other publications follow accurately the behavioral economics approach. Even the World Bank dedicated its report for the world development for 2015 to the behavioral economics. (World Development Report 2015: Mind, Society and Behavior)

Unfortunately, behavioral economics is little known territory at home. Although the most significant western works are already translated in Bulgarian, the efforts for complete presentation of behavioral ideas by Bulgarian authors exhaust by two theoretical studies - my own Architecture of Choice. The Advices of behavioral Economics (2016) and the student book by Atanas Atanasov from University of National and World Economics, behavioral Economics (Atanasov, 2013). There are also few interesting and promising progress studies in the fields of cognitive psychology, organizational relations and behavioral finances. Among the examples are the works of Georgi Karastoyanov in the field of cognitive psychology and particularly his book Psychology of Premeditated Influence (Karastoyanov, 2012) and the study of Marin Paunov in the field of organizational behavior, Human Emotionality in Behavioral Sciences and the Practice of Management (Paunov, 2015).

More quality scientific products are seen in the field of behavioral finances. Standing out among them is the book of Boyan Ivanchev, Everybody Can Invest Successfully if Avoids Illusions and Irrational Behavior (Ivanchev, 2013), also two articles by Teodor Sedlarski and Gergana Dimitrova from Kliment Ohridski University of Sofia - Basic Concepts in the behavioral Finances Theory (Sedlarski \& Dimitrova, 2014) and The World Financial Crisis and the behavioral Finances Perspective (Sedlarski \& Dimitrova, 2016); few publications of Alexander Apostolov from the University of National and World Economics - Key Concepts in the behavioral Finances Theory (Apostolov, 2015), Projection of Profitability of Stock-Traded Assets with Considering Investors' behavioral Characteristics (Apostolov, 2015) and behavioral Approach for Projection of Financial Assets Profitability (Apostolov, 2016) as well as Tsvetan Pavlov's article, Application of behavioral Finances at the Modelling of Bulgarian Shares Risk Premium (Pavlov, 2015) stand out. Nevertheless these positive trends and the increasing interest towards behavioral problematic among the Bulgarian scientific community, the field is still little researched.

\section{CONCLUSION AND PERSPECTIVES}

Behavioral economics is still in the beginning of its development and regarding the methodological aspect, it still does not offer neither systematized knowledge, nor even "standard number of terms and classifications“ (McAuley, 2008). It is early to pronounce it new economic school, yet less pronounce it radical counterpoint of neoclassical paradigm and kind of "revolution" (Tomer, 2007). Libertarian paternalism considers governmental intervention tool for drawing closer the observed behavior of the rationally limited individuals and the theoretical ideal for complete rationality. In this sense, it does not part from the usual notions of rationality. Just the contrary, it appeals for their most consistent practical application: „The irony is that, attacking „Homo Economicus" as empirically false description of decision making process, (the libertarian, author's note), paternalism presents it as a model people should strive for. Or rather - as model of a person, the kind paternalists themselves would like to exist." (Leonard, 2008). Even though being engaged with the positive and perspective issues, behavioral economics does not exchange but corrects and returns neoclassical theory back to its classical roots, supplementing it on one hand, and on the other hand makes some of the assumptions about human behavior more realistic. (Thaler, 2016). The perspectives theory, the avoiding losses concept and hyperbolic discounting are examples for the first. The ideas for the two mental systems, the heuristics and deformations, limited will, social influences and concern about justice are examples for the second one.

Although deep and long-term consequences of the behavioral approach are still in germ, they manifest brighter and visibly. According some researchers, we are even witnessing already the transition from 
traditional „state of prosperity" to a newly structuring model of "new paternalistic state". (Saint-Paul, 2011). Of course, it would be naïve to believe that the formation of "state of new paternalism" results directly from the occurrence of behavioral economics, the persuasiveness and the widely spreading of its ideas. However, it would be wrong to underestimate behavioral economics' role. It gives theoretical grounds and intellectual support to many, elemental until recently, and imposed without any theoretical grounds, forms of governmental intervention and it is this way rationalizing and justifying them. At the same time, it suggests many new, improved paternalistic policies. In the words of J. Saint-Paul "thanks to it the last bastion of rationality in social sciences, what until recently was economics, fell“. (Saint-Paul, 2011). By all that, paternalistic economics contributes to strengthening the paternalistic trends in the functioning of modern states. Is that trend useful? Future will answer.

Has, as a whole, behavioral economics succeeded giving an adequate picture of human behavior and explaining the choices we make? Here the answer is rather negative either. First, because its conclusions are not final and many more studies are necessary in order to be completely confident of their rightness. Second, many more and more different points of view are necessary to solve social problems. behavioral economics increase the possibilities of economic analysis and succeeds there, where others fail, because of its wide frame, which crosses the borders between behavioral sciences and unites their scattered pieces into united new integer. But, as it is with putting frames regarding personal choices, the behavioral economics' frame is not perfect either and is not able to give a complete picture of human behavior. It is only one of the tools that allow to solely get closer to the truth.

\section{REFERENCES LIST}

Апостолов, А.р (2015). Ключови компетенции в теорията на поведенческите фринански.Варна, Икономически университет - Варна,

Апостолов, А., (2015). Проекция на доходността на борсово-търгуваните активи с отчитане на поведенческите особености на инвеститорите. Икономически и социални алтернативи,

Апостолов, А., (2016). Поведенчески подход за проекция на доходността на фринансови активи. Икономически и социални алтернативи.

Ариели, Д., (2012). Предвидимо ирационални: Кои са силите, формиращи нашите решения. София: НСМ - Медиа.

Атанасов, А., (2013). Поведенчески икономикс. София: УНСС.

Иванчев, Б., (2013). Всеки може да инвестира успешно ако избегне илюзиите и ирационалното поведение. София: Изток-запад.

Канеман, Д., (2012). Мисленето. София: Изток-запад.

Карастоянов, Г., (2012). Психология на преднамереното влияние. София: Изток-Запад.

Медина, Д., (2011). 12-те правила на мозъка. София: Изток-Запад.

Павлов, Ц., (2015). Приложение на поведенческите финанси при моделиране на българската рискова премия на акциите. Бизнес управление.

Паунов, М., (2015). Човешката емоционалност в поведенските науки и практиката на управлението. Годишник на УНСС.

Седларски, Т., Димитрова, Г., (2014). Основни концепции в теорията на поведенческите финанси. София, СУ „Св. Климент Охридски”,

Седларски, Т., Димитрова, Г., (2016). Световната фринансова криза и перспективата на поведенческите финанси. София, СУ „Св. Климент Охридски".

Талер, Р., Сънстейн, К., (2014). Побутване. София: Изток-запад.

Хайек, Ф., (1998). Право, законодателство и свобода. София: УИ „Св.Климент Охридски".

Чалдини, Р., (2005). Влиянието. Психология на убеждаването. София: Изток-запад.

Чомски, Н., (2016). Десет начина да Ви манипулират.

Akerlof, G., (2003). behavioral macroeconomics and macroeconomic behavior. The American Economist. Ashraf, N., Camerer, C. and Loewenstein, G., (2005). Adam Smith, behavioral economist. Journal of Economic Perspectives, p. 19(3).

Basham, P., (2010). Are nudging and shoving good for public health?, London: Democracy Institute.

Bovens, L., (2008). The ethics of nudge. Oт: Preference change: Approaches from philosophy, economics and psychology. Berlin and New York: Springer, Theory and Decision Library A.

Camerer, C., (2003). behavioral game theory: Experiments on strategic interaction. Princeton: Princeton University Press.

Camerer, С. и др., (2003). Regulation for Conservatives: behavioral Economics and the Case for 'Asymmetric Paternalism. University of Pennsylvania Law Review, pp. Vol.151. No.1, 
Camerer, C., Loewenstein, G. \& Rabin, M., (2004). Advances in behavioral Economics. Princeton, NJ: Princeton University Press.

Easton, S., (2014). When push comes to shove: inside the NSW nudge unit. The Mandarin, 22 July.

Furedi, F., (2011). Defending moral autonomy against an army of nudgers. Spiked, 20 January.

Gowdy, J., (2008). behavioral economics and climate change policy. Journal of Economic Behavior \& Organization, p. 68(3).

Gruber, J., Köszegi, B., (2001). Is Addiction "Rational"? Theory and Evidence. The Quarterly Journal of Economics, pp. 116(4).

Gruber, J., Mullainathan, S., (2005). Do Cigarette Taxes Make Smokers Happier?. Advances in Economic Analysis and Policy, pp. 20(1).

Grunwald, M., (2009). How Obama is using the science of change. Time Magazine, 2 April, pp.1-9.

Hansen, P., Jespersen, A., (2013). Nudge and the Manipulation of Choice. A Framework for the Responsible Use of the Nudge Approach to Behavior Change in Public Policy. The European Journal of Risk Regulation, pp. 1.

Kahneman, D., (2003). Maps of bounded rationality: Psychology for behavioral economics. American Economics Review.

Kahneman, D., Tversky, A., (1979). Prospect theory: an analysis of decision under risk. Econometrica.

Leonard, T., (2008). Book review: Richard H. Thaler, Cass R. Sunstein, Nudge: Improving decisions about health, wealth, and happiness. Constitutional Political Economy, pp. 19 (4).

McAuley, I., (2008). You can see a lot by just looking: Understanding human judgement in financial decisionmaking, неизв.: Centre for Policy Development.

McCaffery, E., Slemrod, J., (2006). behavioral public finance: Toward a new agenda. New York: Russell Sage Foundation Press.

Mullainathan, S., (2010). Development economics through the lens of psychology, Washington, DC: World Bank.

Mullainathan, S., Thaler, R., (2001). behavioral Economics. OECD, 2017. Use of behavioral insights in consumer policy, Paris.

OECD Science, Technology and Innovation Policy Papers No. 36.

Oullier, O., Sauneron, S., (2010). 'Green Nudges' new incentives for ecological behavior, Paris: Centre d'analyse stratégique. Department of Social affairs. La note d'analyse N 216.

Piniewski, B., Codagnone, C. and Osimo, D., (2011). Nudging lifestyles for better health outcomes: Crowdsourced data and persuasive technologies for behavioral change, Luxembourg: Publications Office of the European Union.

Prentice, R., (2015). behavioral ethics: Can It help lawyers (and others) be their best selves?. Notre Dame Journal of Law, Ethics and Public Policy.

Rizzo, M., Whitman, D., (2009). The knowledge problem of the new paternalism. BYU Law Review.

Saint-Paul, G., (2011). The tyranny of utility: behavioral social science and the rise of paternalism. Princeton: Princeton University Press.

Shleifer, A., (2000). Inefficient markets: An Introduction to behavioral finance. неизв.:Oxford University Press.

Smith, A., (1759). The Theory of Moral Sentiments. London: A. Millar.

Social and behavioral Sciences Team, (2016). Annual Report, (2016), Washington, DC: National Science and Technology Council, Executive Office of the President.

Sunstein, C., (2013). The Storrs lectures: behavioral economics and paternalism. The Yale Law Journal.

Sunstein, C., Reisch, L., (2017). The economics of nudge. От: C. Sunstein L. Reisch, ред. Critical Concepts of Economics, Vol. 4. London: Routledge.

Thaler, R., (2016), behavioral economics: Past, present, and future.

Thaler, R. Sunstein, C., (2003). Libertarian paternalism. American Economic Review.

The Economist, (2011). Not so smart now. The Economist, 29 October.

Tomer, J., (2007). What is behavioral economics?. The Journal of Socio-Economics.

Tversky, A. ,Kahneman, D., (1974). Judgment under uncertainty: Heuristics and biases. Science.

White, M., (2013). The manipulation of choice. New York: Palgrave Macmillan. 